\title{
Sustainable Property: What Form Should Ownership Take in the 21st Century?
}

\author{
Harvey M Jacobs ${ }^{1,2 *}$ \\ ${ }^{1}$ Professor, University of Wisconsin-Madison, USA \\ ${ }^{2}$ Visiting Professor, Radboud University Nijmegen, The Netherlands
}

Submission: March 16, 2020; Published: July 08, 2020

*Corresponding author: Harvey M Jacobs, Professor, University of Wisconsin-Madison, USA \& Visiting Professor, Radboud University Nijmegen, The Netherlands, 4629 Keating Terrace, Madison, WI, 53711, USA

\section{Introduction}

This is an era when many long-standing institutions are under severe strain - the fundamental structure of the economy, the functionality of globalization vis-a-vis production, trade, and immigration, notions of citizenship, racial relations, and environmental management are among these. Substantial progress seemed to have been made about environmental management since the 1960s. Yet the issues of the present - e.g. climate change, freshwater shortages, radically changing weather patterns, coastal zone fragility, more frequent wildfires, among others - raise questions about the continued relevancy of the $1960 \mathrm{~s}$ environmental management model. And the tension between environmental management and economic development ('getting the economy going again') lead some to suggest that sustainability is a luxury that cannot be indulged. Central to this discussion is the question of what form of environmental and natural resource ownership is appropriate for long-term sustainability.

\section{Discussion}

Since humans organized into societies, they have developed structures to own natural resources [1]. In pre-modern times these ownership forms were often tribal, commons-based, communal, and-or royal property. As modern times evolved, private and then public property came to the fore. Private property is an old idea [2]. But it, like other old ideas - democracy and a market economy - fully came into its own only with the so-called Age of Discovery (the Age of Exploration) [3]. As Europeans began to 'discover' the world, they undertook to possess its many natural resources, initially in the name of royalty. But over the century's ideas emerged about the rights of citizens - in governance, and within a market economy. The work of John Locke, Jean-Jacques Rousseau, and Adam Smith in the $17^{\text {th }}$ and $18^{\text {th }}$ centuries laid out a new vision of the individual where s/he had rights, including the right to own and control property [4]. And in so doing, the individual working for their own self-interest would in turn serve the greater social interest.

Locke and Rousseau's political visions had impact on the American and French revolutions of the late 1700s. In the French Declaration of the Rights of Man in 1789, and the American Bill of (Human) Rights, addended to the U.S. Constitution in 1791, powerful statements were offered about the importance - the sanctity - of private property for the integrity of the new political regime. (Right 17 of the French Declaration of the Rights of Man states: Property being an inviolable and sacred right, no one may be deprived of it except when public necessity, certified by law, obviously requires it, and on the condition of a just compensation in advance.). Thus, accelerated a multi-century process where private property came to dominate other forms of property in the West, and the West sought to replace non private forms of property globally. And for many (though not all) the trend seemed a reasonable trade off. Economic progress ensued, and for many (though not all) standards of living improved [5].

But the modern environmental movement brought the process to a screeching halt. By the late 20th century air pollution, water pollution, species extinction, soil erosion, deforestation, desertification, and a panoply of other environmental problems were ever present and of ever growing concern to an ever wider community of citizens in both the developed and developing worlds. Why were they occurring? 
According to some, for the same reason that progress has continued apace for the preceding centuries - the widespread existence of private property. In 1968 Garret Hardin published what has become the most read article in environmental management: The Tragedy of the Commons [6]. While ostensibly written about commons resources - the atmosphere, oceans, fisheries - its central point became one applied to almost all environmental problems: individual user-owners (including corporations and governments) pursued their own self-interest to the exclusion of the interest of others and the society and ecology at large. The result was a tragedy - a crisis in sustainability for the resource. This was as true for commons resources - e.g. the atmosphere - as it was for privately owned resources, e.g. farmland at the urban fringe. Environmentalists took from this a pointed critique of private property. It was because owners laid claim to and controlled natural resources and sought to benefit from them - often responding to 'rational' signals from the market - that all sorts of environmental problems arose and endured [7].

In embracing Hardin, modern environmentalists opened the search for an alternative. Environmental advocates have argued for extending property rights to nature, revising the bundle of rights to include a 'green stick', and revising the core property concept so that it includes not only rights, but (social) responsibilities, among some of the proposals [8-12].

But this conclusion - that private property is the source of environmental problems, and that ownership needs to change for sustainability to be realized - quickly became socially contested. Hardin himself argued for a privatization as a strategy for sustainability. Ostrom, winner of the 2009 Nobel Prize in Economics, showed that Hardin's core idea (i.e. that common property always resulted in a tragedy) might not be as universal as he and others believed, and that common property could be quite sustainable [13]. And another group of scholars argued that in fact private ownership of property was not at all the problem, but rather the solution for sustainability. According to their analyses, markets, and robust property rights properly structured were a far better solution than state-based regulation, or re-structured property rights bundles $[14,15]$.

Which perspective is correct? The answer is not clear. There are a range of proposals - some radical, some moderate, some status quo - all of which can be convincingly argued. Yet private property has been subject to widespread critiques for well over a century. Beginning in the latter part of the $19^{\text {th }}$ century and continuing through the $20^{\text {th }}$ century ecologists have been deeply bothered by what happens to landscapes and resources when an owner is primarily concerned with their own benefit $[16,17]$.

\section{Conclusion}

This period of history begs for new ideas about sustainability. One of these ideas must be a critical examination of the form ownership should take for sustainable environmental management [18]. At other times in human history other forms of ownership seemed to have fit with sustainability. But circumstances always changed - the macro-ecology, production practices, urbanization, density, are some examples - and what worked for one period no longer worked. The social and legal institution of property must adapt. The one that has been common in the West for several hundred years was functional in an era of abundant natural resources, a largely rural population, and broad-scale economic growth. We need the courage to envision new property forms for new ecological, public health, spatial, social, and economic conditions [19].

\section{References}

1. YN Harari (2015) Sapiens: A Brief History of Humankind. Harper Collins, New York, NY, USA.

2. R Schlatter (1951) Private Property: The History of an Idea. Rutgers University Press, New Brunswick, NJ, USA.

3. W Ophuls (1977) Ecology and the Politics of Scarcity: Prologue to a Political Theory of the Steady State. W H Freeman \& Co, New York, NY, USA.

4. Ophuls (1977).

5. T Bethell (1998) The Noblest Triumph: Property and Prosperity Through the Ages. St. Martin's Press, New York, NY, USA.

6. G Hardin (1968) The tragedy of the commons. Science 162(3859): 1243-1248.

7. Sinden (2007) The tragedy of the commons and the myth of a private property solution. University of Colorado Law Review 78(2): 533-612.

8. C Stone (1972) Should trees have standing: Toward legal rights for natural objects. Southern California Law Review 45(2): 450-501.

9. DW Large (1973) This land is whose land? Changing concepts of land as property. Wisconsin Law Review 1973: 1039-1083.

10. RJ Goldstein (2004) Ecology and Environmental Ethics: Green Wood in the Bundle of Sticks. Ashgate, Burlington, VT.

11. CC Geisler, G Daneker (2000) Property and Values: Alternatives to Public and Private Ownership. Island Press, Washington, DC, USA.

12. B Davy (2020) 'Dehumanized housing' and the ideology of property as a social function. Planning Theory 19(1): 38-58.

13. E Ostrom (1990) Governing the Commons: The Evolution of Institutions for Collective Action. Cambridge University Press, New York, NY, USA.

14. TL Anderson, DR Leal (1991) Free Market Environmentalism. Westview Press, San Francisco, CA, USA.

15. TL Anderson, GD Libecap (2014) Environmental Markets: A Property Rights Approach. Cambridge University Press, New York, NY, USA.

16. GP Marsh (1864) Man and Nature; or Physical geography as modified by human action. New York, USA.

17. C Scribner, A Leopold (1949) A Sand County Almanac. New York: Oxford University Press, Land Ethic, pp. 201-226.

18. HM Jacobs (2018) Eighteenth-century property rights for twenty-first-century environmental conditions? In: $\mathrm{F}$ van der Straalen, $\mathrm{T}$ Hartmann, J Sheehan (Eds.), Property Rights and Climate Change: Land-Use Under Changing Environmental Conditions. Routledge, London, UK, pp. 41-51.

19. HM Jacobs, B Davy, S Pellissery (2020) Pandemics, planning, and property. Town Planning Review 91: (forthcoming). 
Your next submission with Juniper Publishers will reach you the below assets

- Quality Editorial service

- Swift Peer Review

- Reprints availability

- E-prints Service

- Manuscript Podcast for convenient understanding

- Global attainment for your research

- Manuscript accessibility in different formats

( Pdf, E-pub, Full Text, Audio)

- Unceasing customer service

Track the below URL for one-step submission https://juniperpublishers.com/online-submission.php 